\title{
Effects of 50 Percent Substitution of Soybean Meal by Alternative Proteins from Hermetia illucens or Spirulina platensis in Meat-Type Chicken Diets with Graded Amino Acid Supply
}

\author{
Susanne Velten', Carmen Neumann', Martina Bleyer², Eva Gruber-Dujardin², \\ Maria Hanuszewska ${ }^{3}$, Barbara Przybylska-Gornowicz ${ }^{4}$, Frank Liebert ${ }^{1}$ \\ ${ }^{1}$ Department of Animal Sciences, Division Animal Nutrition Physiology, Georg-August-University of Goettingen, Goettingen, \\ Germany \\ ${ }^{2}$ German Primate Center GmbH, Pathology Unit, Goettingen, Germany \\ ${ }^{3}$ Department of Poultry Science, University of Warmia and Mazury in Olsztyn, Olsztyn, Poland \\ ${ }^{4}$ Department of Histology and Embryology, Faculty of Veterinary Medicine, University of Warmia and Mazury in Olsztyn, \\ Olsztyn, Poland \\ Email: flieber@gwdg.de
}

How to cite this paper: Velten, S., Neumann, C., Bleyer, M., Gruber-Dujardin, E., Hanuszewska, M., Przybylska-Gornowicz, B. and Liebert, F. (2018) Effects of 50 Percent Substitution of Soybean Meal by Alternative Proteins from Hermetia illucens or Spirulina platensis in Meat-Type Chicken Diets with Graded Amino Acid Supply. Open Journal of Animal Sciences, 8, 119-136. https://doi.org/10.4236/ojas.2018.82009

Received: February 8, 2018

Accepted: April 6, 2018

Published: April 11, 2018

Copyright $\odot 2018$ by authors and Scientific Research Publishing Inc. This work is licensed under the Creative Commons Attribution International License (CC BY 4.0).

http://creativecommons.org/licenses/by/4.0/ (c) (i) Open Access

\begin{abstract}
Alternative protein sources, such as insects or algae meals are in special focus of animal nutrition in order to replace soybean meal (SBM). As part of the multidisciplinary project "sustainability transitions" this study evaluated effects of replacing SBM by partly defatted larvae meal from the black soldier fly, Hermetia illucens or meal from the micro algae Spirulina platensis in broiler diets. The aim of the current study was to investigate the chickens' growth performance and the intestinal morphology as well as the health status. 288 one-day-old male growing chickens (Ross 308 ) from a commercial hatchery were randomly allotted to 48 pens ( 6 birds per pen) for the growth study with five diets and feed supply on free choice level. The control diet was based on wheat, corn and SBM. The experimental diets replaced 50\% of SBM by the alternative proteins under study, both on a basic level of amino acid (AA) supplementation (Lys and Met added equal to the control diet) (diet HM and SM) and an extended level of AA fortification (Lys, Met, Thr, Arg, Val added) (diet $\mathrm{HM}+$ and $\mathrm{SM}+$ ). Response of chickens was evaluated by zoo-technical parameters, which were under weekly control (e.g. growth, feed intake, feed conversion ratio, mortality). After finishing the growth study birds from control and the experimental diets at the basic level of AA supplementation were slaughtered after 12 hour fastening and utilized for gut morphometric analysis and histological evaluation of the health status. Diets at a
\end{abstract}


basic level of AA fortification led to significant depression of growth, feed intake, feed conversion ratio, and protein conversion ratio, respectively. In addition, the acceptance of the Spirulina diet was lower $(\mathrm{p} \leq 0.001)$ as compared to the Hermetia based diet. However, the extended level of AA supplementation improved all parameters significantly. Diets without extended AA supply altered some morphological parameters of the intestinal wall, but the nutritional significance of this observation needs to be verified in AA balanced diets. The health state of chicken was not impaired by the diets under study.

\section{Keywords}

Growing Chickens, Feed, Growth Performance, Histology, Morphometry, Spirulina platensis, Hermetia illucens

\section{Introduction}

Soybean meal is the main feed protein source in diet formulation for pigs and poultry in EU. According to the projections of the Food and Agricultural Organization of the United Nations (FAO), the world's population will increase to nine billion people in 2050 [1] and it is expected that more food from animal origin will be needed [2]. According to [3], it is possible to feed the world 's population with a vegetarian diet; however such a change in consumer demands and preferences is not expected in the near future. In consequence, more protein feed for nutrient transformation by livestock is required while concurrently meeting the needs of human nutrition.

As alternatives to traditional feed proteins, insects have gained increased attention in Europe [4] because of their high protein content and adequate amino acid composition, which is widely comparable to conventional animal proteins, associated with various fatty acids, minerals and vitamins [5] [6] [7] [8]. Black soldier fly (Hermetia illucens) is one of the most promising species in terms of larval nutritional value [9]. [10] pointed out that Hermetia larvae meal is an excellent source of protein and energy in diets for growing chickens. They were able to show that the growth rate of chickens was improved when HM was applied as an ingredient of a complete broiler feed [11]. However, only limited information is available in order to optimize the use of Hermetia meal in broiler diets [10] [12]. Presently, in Europe, insect-based meals are not allowed to be included in livestock and poultry feeds [13]. Nonetheless, since 1 July 2017, processed insect protein has been authorized for the use in aquaculture by Regulation [14]. Therefore, the EU barriers are expected to be overcome in the future so that this promising protein source could be integrated into poultry diets.

An additional alternative protein source is blue-green algae meal from Spirulina platensis, which is widely considered as a potential livestock feed ingredient due to its high protein content and the abundance of vitamins, pigments and minerals [15] [16] [17]. Spirulina meal is suitable as a substitute for conventional 
ingredients in poultry nutrition and has thus far been shown to yield no detrimental effects when up to 15\% Spirulina meal was included in broiler feeds [18]. However, detailed investigations about the optimized application of Spirulina in chicken diets are scarce.

As part of the multidisciplinary project "Sustainability Transitions in food production: alternative protein sources from a socio-technical perspective", the present study aimed to evaluate the potential of Hermetia and Spirulina meal as alternative feed proteins for the substitution of soybean meal (SBM) in diets for meat type chickens. In a first step, 50\% replacement of SBM was examined and the zoo-technical data are presented in the current study. According to earlier observations [19] [20], the intestinal morphology could also be affected at high inclusion rates of Hermetia or Spirulina. In consequence, histological analysis was an integrated part of the investigations.

\section{Material and Methods}

The experiments were conducted at the Division for Animal Nutrition Physiology at the Georg-August-University Goettingen and approved by the Ethics Committee of the Lower Saxony Federal Office for Consumer Protection and Food Safety (LAVES), Germany.

\subsection{Stock and Husbandry}

A total of 288 day-old male growing chickens (Ross-308 line; WIMEX Agrarprodukte, Hatchery Rosefeld Germany) were randomly allotted to 48 floor pens (6 birds/pen) one day after hatching. Based on individual body weight (BW) of birds it was aimed to achieve a similar average BW at the experiment start for the five experimental treatments under study (Control diet, $\mathrm{n}=12$; 4 experimental diets, $n=9$ ). In an environmentally controlled room with monochromatic (red) light for 23 hours, birds were bedded on wood shavings and had full access to feed and water. Climatic conditions were chosen according to the Ross management recommendations [21]. Experimental conditions were routinely checked twice daily with special attention to feeders, water supply, temperature and physiological state of chickens. Physiological state of chickens was measured by health and vitality of the birds. Growth data and feed consumption were recorded weekly.

\subsection{Alternative Protein Sources}

The investigated Hermetia meal was obtained from a commercial producer (Hermetia Futtermittel GbR, Baruth/Mark, Germany). Black soldier fly larvae were collected from a plant-based substrate (rye flour, wheat bran) after 20 days of fattening. Following 14 hours of drying at temperatures between $65^{\circ} \mathrm{C}$ and $70^{\circ} \mathrm{C}$, the larvae were partly defatted with a screw press (Type AP08, Reinartz) and afterwards ground into a meal.

The Spirulina platensis microalga used in the study was a sun-dried commer- 
cial Spirulina source powder obtained from Myanmar and declared to be free of GMO, irradiation, pesticides, colorants, preservatives and additives. As demonstrated by the nutrient composition of the protein sources (Table 1), the lipid fraction was not extracted from the algae meal. The microcystine content was analyzed by an external laboratory (TeLA GmbH, Geestland, Germany) and remained under the detection limit. The nutritional contents of the final alternative protein source products are shown in Table 1.

\subsection{Diets and Feeding}

Experimental diets were mixed and pelleted at the facilities of the Division for Animal Nutrition Physiology at the University of Goettingen. Pelleted diets were supplied ad libitum as starter ( $1-21 \mathrm{~d}$ ) and grower diets (22 - $34 \mathrm{~d})$. The starter/ grower control diets were based on wheat (33/38\%), corn (16/19\%) and SBM $(39 / 32 \%)$ as the main ingredients (Table 2). Experimental diets aimed to substitute $50 \%$ of the SBM in the control diet by the alternative proteins under study, both with a basic and an extended level of AA fortification. The basic level diets (HM and SM, respectively) were individually adjusted by Lys and Met supplementation so that they were equal to that of the control diet. The extended level of AA fortification (diet $\mathrm{HM}+$ and diet $\mathrm{SM}+$, respectively) aimed to yield an improved dietary AA balance according to an ideal AA ratio (IAAR) as currently recommended by [22]. Consequently, in these diets, beside Lys and Met, further

Table 1. Analyzed crude nutrient and AA composition of Spirulina platensis and Hermetia illucens meals as used for diet formulation.

\begin{tabular}{|c|c|c|c|c|}
\hline Nutrient contents & \multicolumn{2}{|c|}{ Hermetia meal } & \multicolumn{2}{|c|}{ Spirulina meal } \\
\hline Moisture (\%) & \multicolumn{2}{|c|}{5.5} & \multicolumn{2}{|c|}{3.4} \\
\hline Crude protein (\% of DM) & \multicolumn{2}{|c|}{60.8} & \multicolumn{2}{|c|}{58.8} \\
\hline Crude ash (\% of DM) & \multicolumn{2}{|c|}{7.5} & \multicolumn{2}{|c|}{6.1} \\
\hline Crude lipids (\% of DM) & \multicolumn{2}{|c|}{14.1} & \multicolumn{2}{|c|}{4.3} \\
\hline Crude fibre (\% of DM) & \multicolumn{2}{|c|}{10.9} & \multicolumn{2}{|c|}{$0.5^{*}$} \\
\hline AA contents & $\mathrm{gAA} / \mathrm{kgDM}$ & $\mathrm{gAA} / 16 \mathrm{gN}$ & gAA/kgDM & $\mathrm{gAA} / 16 \mathrm{gN}$ \\
\hline Lys & 32.97 & 5.42 & 22.97 & 3.91 \\
\hline Met & 7.53 & 1.24 & 10.61 & 1.81 \\
\hline Cys & 4.89 & 0.80 & 4.53 & 0.77 \\
\hline Thr & 21.70 & 3.57 & 25.77 & 4.39 \\
\hline Arg & 25.05 & 4.12 & 39.92 & 6.79 \\
\hline Val & 32.58 & 5.36 & 34.50 & 5.87 \\
\hline Leu & 37.95 & 6.24 & 47.23 & 8.04 \\
\hline Ile & 23.47 & 3.86 & 29.81 & 5.07 \\
\hline His & 16.58 & 2.73 & 7.51 & 1.28 \\
\hline
\end{tabular}

* preliminary data due to difficulties in application of the standard procedure. 
Table 2. Ingredient composition of experimental diets ( $\mathrm{g} / \mathrm{kg}$ as fed).

\begin{tabular}{|c|c|c|c|c|c|c|c|c|c|c|}
\hline \multirow{2}{*}{$\begin{array}{l}\text { Ingredients/ } \\
\text { Diets }\end{array}$} & \multicolumn{5}{|c|}{ Starter period $(1-21 \mathrm{~d})$} & \multicolumn{5}{|c|}{ Grower period $(22-34 d)$} \\
\hline & Control & $\mathrm{HM}$ & SM & $\mathrm{HM}+$ & SM+ & Control & $\mathrm{HM}$ & SM & $\mathrm{HM}+$ & SM+ \\
\hline Wheat & 328.8 & 362.8 & 381.5 & 358.3 & 377.9 & 375.8 & 405.8 & 419.1 & 402.6 & 416.8 \\
\hline Corn & 164.4 & 181.4 & 190.7 & 179.2 & 189.0 & 187.9 & 202.9 & 209.6 & 201.3 & 208.4 \\
\hline Soybean meal & 390 & 195.0 & 195.0 & 195.0 & 195.0 & 320.0 & 160.0 & 160.0 & 160.0 & 160.0 \\
\hline Insect meal & - & 145.4 & - & 145.4 & - & - & 119.0 & - & 119.0 & - \\
\hline Algae meal & - & - & 118.2 & - & 118.2 & - & - & 97.0 & - & 97.0 \\
\hline Soybean oil & 78.5 & 78.5 & 78.5 & 78.5 & 78.5 & 78.5 & 78.5 & 78.5 & 78.5 & 78.5 \\
\hline Premix $^{1}$ & 10.0 & 10.0 & 10.0 & 10.0 & 10.0 & 10.0 & 10.0 & 10.0 & 10.0 & 10.0 \\
\hline DCP 40 & 11.0 & 12.0 & 12.0 & 12.0 & 12.0 & 10.0 & 8.0 & 10.0 & 8.0 & 10.0 \\
\hline $\mathrm{CaCO}_{3}$ & 11.0 & 9.9 & 9.1 & 9.9 & 9.1 & 9.0 & 8.0 & 8.0 & 8.0 & 8.0 \\
\hline $\mathrm{NaCl}$ & 3.0 & 1.7 & 1.7 & 1.7 & 1.7 & 3.0 & 2.0 & 2.0 & 2.0 & 2.0 \\
\hline Wheat starch & - & - & - & - & - & - & - & - & 3.0 & 3.0 \\
\hline $\mathrm{TiO}_{2}$ & - & - & - & - & - & 3.0 & 3.0 & 3.0 & - & - \\
\hline L-Lys $\cdot \mathrm{HCl}$ & 1.3 & 1.3 & 1.3 & 3.2 & 4.4 & 0.8 & 0.8 & 0.8 & 2.4 & 3.5 \\
\hline DL-Met & 2.0 & 2.0 & 2.0 & 4.1 & 3.5 & 2.0 & 2.0 & 2.0 & 3.0 & 2.5 \\
\hline L-Thr & - & - & - & 0.6 & - & - & - & - & 0.4 & - \\
\hline L-Arg & - & - & - & 2.2 & 0.7 & - & - & - & 1.4 & 0.1 \\
\hline L-Val & - & - & - & - & - & - & - & - & 0.5 & 0.2 \\
\hline
\end{tabular}

$\mathrm{HM}=$ Hermetia meal diet with basic AA supply; $\mathrm{SM}=$ Spirulina meal diet with basic AA supply; HM+ = Hermetia meal diet with extended AA supply; SM+ = Spirulina meal diet with extended AA supply. ${ }^{1}$ Added per $\mathrm{kg}$ of final diet: $2.1 \mathrm{~g}$ calcium, $0.8 \mathrm{~g}$ sodium, $5000 \mathrm{IU}$ vitamin $\mathrm{A}, 1000 \mathrm{IU}$ vitamin D3, $30 \mathrm{mg}$ vitamin $\mathrm{E}$, $2.6 \mathrm{mg}$ vitamin B1, $4.8 \mathrm{mg}$ vitamin B2, $3.2 \mathrm{mg}$ vitamin B6, $20 \mu \mathrm{g}$ vitamin B12, $3 \mathrm{mg}$ vitamin $\mathrm{K} 3,50 \mathrm{mg}$ nicotinic acid, $10 \mathrm{mg}$ calcium pantothenate, $0.9 \mathrm{mg}$ folic acid, $100 \mu \mathrm{g}$ biotin, $1000 \mathrm{mg}$ choline chloride, $50 \mathrm{mg} \mathrm{Fe}$ as iron-II-sulfate, monohydrate, $15 \mathrm{mg} \mathrm{Cu}$ as copper-II-sulfate, pentahydrate, $120 \mathrm{mg} \mathrm{Mn}$ as manganese-II-oxide, $70 \mathrm{mg} \mathrm{Zn}$ as zinc oxide, $1.4 \mathrm{mg} \mathrm{I}$ as calcium iodate, hexahydrate, $0.28 \mathrm{mg}$ Se as sodium selenite, $0.55 \mathrm{mg}$ Co as alkaline cobalt-II-carbonate, monohydrate and $100 \mathrm{mg}$ butylhydroxytoluol.

AAs (Thr, Arg, Val) were supplemented. Analyzed nutrient composition of the diets is summarized in Table 3.

\subsection{Recorded Parameters}

\subsubsection{Feed Analysis}

All Analyses of ingredients and experimental diets were conducted according to the standards of German VDLUFA [24]. Nitrogen content of feed was measured using the DUMAS-method (TruMac ${ }^{\circledR}$, Leco Instrument GmbH, Mönchengladbach). The calculation of fraction $\mathrm{CP}$ was based on factor 6.25 of the nitrogen content. The given AA contents of the final diets are based on the analyzed AA contents of the single protein sources. AA composition of the protein sources were analyzed through ion-exchange chromatography (Biochrom ${ }^{\circledR} 30$, Biochrom Ltd. Cambridge, England) using acid hydrolysis with and without an oxidation step quantitative determination of sulphur-containing AAs. According to the 
Table 3. Analyzed content of crude nutrients and selected AAs of experimental diets.

\begin{tabular}{|c|c|c|c|c|c|c|c|c|c|c|}
\hline \multirow{2}{*}{ Diets } & \multicolumn{5}{|c|}{ Starter period $(1-21 \mathrm{~d})$} & \multicolumn{5}{|c|}{ Grower period $(22-34 d)$} \\
\hline & Control & HM & SM & $\mathrm{HM}+$ & SM+ & Control & HM & SM & HM+ & SM+ \\
\hline & \multicolumn{10}{|c|}{ Crude nutrients ( $g / \mathrm{kgDM})$} \\
\hline Crude protein & 249.5 & 249.6 & 236.4 & 259.3 & 241.4 & 220.2 & 217.7 & 207.4 & 230.9 & 207.2 \\
\hline Ether extract & 111.6 & 124.3 & 115.7 & 131.1 & 116.6 & 112.8 & 110.7 & 117.2 & 131.4 & 118.4 \\
\hline Crude fiber & 45.2 & 49.4 & 33.4 & 47.1 & 31.1 & 40.4 & 41.1 & 28.5 & 41.7 & 30.4 \\
\hline Crude ash & 65.6 & 60.1 & 58.1 & 60.4 & 59.2 & 61.6 & 55.6 & 55.2 & 56.5 & 53.5 \\
\hline $\mathrm{N}$-free extract & 528.1 & 516.6 & 556.4 & 502.1 & 551.7 & 565 & 574.9 & 591.7 & 539.5 & 590.5 \\
\hline \multirow[t]{2}{*}{$\begin{array}{c}\mathrm{AME}_{\mathrm{N}} \\
(\mathrm{MJ} / \mathrm{kgDM})^{1}\end{array}$} & 14.4 & 15.2 & 15.4 & 15.3 & 15.4 & 14.8 & 15.5 & 15.6 & 15.6 & 15.6 \\
\hline & \multicolumn{10}{|c|}{ Amino acids ( $g / \mathrm{kg}$ as-fed $)^{2}$} \\
\hline Lys & 12.55 & 12.20 & 10.24 & 13.66 & 12.68 & 10.53 & 10.24 & 8.64 & 11.48 & 10.73 \\
\hline Met & 4.99 & 4.96 & 5.13 & 7.01 & 6.60 & 4.63 & 4.68 & 4.82 & 5.6 & 5.31 \\
\hline Met+Cys & 8.43 & 8.06 & 8.12 & 10.10 & 9.58 & 7.87 & 7.57 & 7.62 & 8.49 & 8.10 \\
\hline Thr & 7.84 & 7.86 & 7.8 & 8.38 & 7.78 & 6.92 & 6.94 & 6.89 & 7.27 & 6.88 \\
\hline Arg & 14.25 & 11.95 & 13.03 & 14.09 & 13.65 & 12.4 & 10.52 & 11.41 & 11.88 & 11.49 \\
\hline Val & 9.34 & 10.43 & 9.85 & 10.40 & 9.83 & 8.31 & 9.21 & 8.73 & 9.68 & 8.92 \\
\hline
\end{tabular}

$\mathrm{HM}=$ Hermetia meal diet with basic AA supply; $\mathrm{SM}=$ Spirulina meal diet with basic AA supply; $\mathrm{HM}+=$ Hermetia meal diet with extended AA supply; SM+ = Spirulina meal diet with extended AA supply. ${ }^{1} \mathrm{~N}$ corrected apparent metabolizable energy, calculated according to [23]; ${ }^{2}$ Derived from analyzed AA content of the ingredients.

German standards, ether extracts were analyzed following $\mathrm{HCl}$ hydrolysis of the feed samples.

\subsubsection{Performance Parameters}

Feed intake (FI), BW and mortality were measured during the growth trial. Individual body weight and pen feed intake were recorded at weekly intervals. From these data, the feed conversion ratio (FCR) (see Equation (1)) and the protein conversion ratio (see Equation (2)) were calculated. Mortality was routinely checked twice daily.

$$
\begin{gathered}
F C R=\frac{D M_{\text {intake }}}{B W_{\text {gain }}} \\
P C R=\frac{C P_{\text {intake }}}{B W_{\text {gain }}}
\end{gathered}
$$

whereby

$$
\begin{aligned}
& F C R=\text { feed conversion ratio }(\mathrm{g} / \mathrm{g}) \\
& P C R=\text { protein conversion ratio }(\mathrm{g} / \mathrm{g}) \\
& D M_{\text {intake }}=\text { dry matter intake }(\mathrm{g}) \\
& B W_{\text {gain }}=\text { body weight gain }(\mathrm{g}) \\
& C P_{\text {intake }}=\text { crude protein intake }(\mathrm{g})
\end{aligned}
$$




\subsubsection{Histological Examinations}

\section{Verification of health status}

For the histological evaluation of the health status, eight chickens per diet from selected treatments (control, HM and SM) were slaughtered and weighed after 12 hours fastening. Representative tissue specimen from liver, spleen, lung, heart, pancreas, kidney, glandular stomach, gizzard, caecum, colon and Bursa of Fabricius were fixed in formalin solution (4\%), paraffin-embedded and cut into $4 \mu \mathrm{m}$ tissue sections before being routinely stained with hematoxylin and eosin (HE) for microscopy. A certified specialist in veterinary pathology, comprehensively blind of different experimental treatments, examined histological specimens of all animals for pathological changes. Furthermore, the presence of inflammatory cell infiltrates within tissues/organs were semi-quantitatively evaluated by an ordinal scoring system ( 0 normal, $(+)$ scarce, + mild, ++ moderate, +++ severe) according to [25].

Gut morphometric analysis

Twelve chickens per selected diet (control, HM and SM) were randomly quoted in order to conduct histological analyses of the intestine. Birds were killed by $\mathrm{CO}_{2}$ inhalation and 10 to $15 \mathrm{~min}$. later tissue samples (approximately $10 \mathrm{~mm} \times 5 \mathrm{~mm}$ ) were taken from three sections (the middle of the descending part of the duodenum, the middle of the jejunum behind Meckel's diverticulum and the middle of the left caecum). Tissue samples were flushed with saline and fixed in 10\% neutral buffered formalin solution, dehydrated in ethanol (TP 1020, Leica, Germany) and embedded in paraffin (EG 1150, Leica, Germany). For microscopy, the $5-\mu \mathrm{m}$-thick sections were prepared by a microtome (HM $340 \mathrm{E}$, Microm, Spain) and stained with hematoxylin and eosin making use of an automated multistainer ST 5020 (Leica, Germany). Morphometric analyses were performed in samples selected by systematic random sampling - every $30^{\text {th }}$ section was chosen to obtain six sections of duodenal, jejunal or caecal tissue per bird. The slides were scanned in a MiraxDesk scanner (Carl Zeiss, Germany) and analyzed using the Pannoramic Viewer 1.15.4 software (3D-Histech, Hungary). The following measurements were performed: villi length, depth of the crypts of Lieberkühn, ratio of villus length to crypt depth and thickness of the tunica muscularis, respectively. The linear measurements were repeated 10 times per animal and the calculated mean value was applied for further assessments.

\subsection{Statistical Analysis}

Growth performance

Results are presented as means \pm standard deviation (Mean \pm SD). Statistical analysis was carried out using the software package SPSS (IBM SPSS Statistics, Version 24.0). One-way ANOVA were run using the Tukey-test and GamesHowell-test to identify significant differences between treatments $(p \leq 0.05)$.

Gut morphometric analysis

For gut morphometric analysis, the data were analyzed using one-way ANOVA. Statistical analyses were performed using the Statistica 10.0 software 
(StatSoft, USA). The significance of differences between means was evaluated by Duncan's test $(\mathrm{p} \leq 0.05)$.

\section{Results}

\subsection{Growth Trial}

Results of the growth trial are summarized in Table 4.

In the starter period, both the HM and SM diets led to a significant decline in dry matter intake, growth and feed efficiency as compared to the control diet and diets with extended AA supplementation ( $\mathrm{HM}+$ and $\mathrm{SM}+)$. The acceptance of the SM diet was lower ( $\mathrm{p} \leq 0.001)$ as compared to the other diets (control, $\mathrm{HM}, \mathrm{HM}+$ and $\mathrm{SM}+$ ). In contrast, diets $\mathrm{HM}+$ and $\mathrm{SM}+$ compensated for these observed depressions in all mentioned parameters. Diet $\mathrm{HM}+$ did provide significantly superior results for BW, compared to the control group.

During the grower period, the HM and SM diets continued to yield significantly lower BW and feed intake rates. Feed- and protein conversion ratios were impaired as compared to the control, $\mathrm{HM}+$ and $\mathrm{SM}+$ diets. As was observed in

Table 4. Summarized performance results of the growth study in starter and grower period and over the whole 5 weeks trial of growing meat type chicken*.

\begin{tabular}{|c|c|c|c|c|c|c|c|}
\hline Diet & Control & $\mathrm{HM}$ & SM & $\mathrm{HM}+$ & SM+ & \multirow{2}{*}{ SEM } & \multirow{2}{*}{$p$} \\
\hline $\mathbf{n}$ & 12 & 9 & $8^{* *}$ & 9 & 9 & & \\
\hline \multicolumn{8}{|l|}{ Starter period (d1-21) } \\
\hline Day old chicken (g) & $47.5 \pm 0.1$ & $47.4 \pm 0.1$ & $47.3 \pm 0.1$ & $47.3 \pm 0.2$ & $47.3 \pm 0.2$ & 0.025 & 0.304 \\
\hline Final body weight (g) & $960.9^{c} \pm 50.5$ & $693.2^{\mathrm{b}} \pm 30.1$ & $504.6^{\mathrm{a}} \pm 31.0$ & $1034.5^{\mathrm{d}} \pm 42.0$ & $947.3^{c} \pm 60.1$ & 28.811 & $<0.001$ \\
\hline Dry matter intake (g/d) & $54.3^{\mathrm{cd}} \pm 3.8$ & $47.1^{\mathrm{b}} \pm 3.7$ & $37.7^{\mathrm{a}} \pm 3.4$ & $58.0^{\mathrm{d}} \pm 4.1$ & $52.6^{\mathrm{c}} \pm 4.6$ & 1.164 & $<0.001$ \\
\hline Feed conversion ratio $(\mathrm{g} / \mathrm{g})$ & $1.25^{\mathrm{a}} \pm 0.11$ & $1.53^{\mathrm{b}} \pm 0.13$ & $1.70^{c} \pm 0.1$ & $1.23^{\mathrm{a}} \pm 0.07$ & $1.23^{\mathrm{a}} \pm 0.04$ & 0.030 & $<0.001$ \\
\hline Protein conversion ratio $(\mathrm{g} / \mathrm{g})$ & $0.31^{\mathrm{a}} \pm 0.03$ & $0.38^{\mathrm{b}} \pm 0.03$ & $0.40^{\mathrm{b}} \pm 0.02$ & $0.32^{\mathrm{a}} \pm 0.02$ & $0.29^{\mathrm{a}} \pm 0.01$ & 0.007 & $<0.001$ \\
\hline \multicolumn{8}{|l|}{ Grower period (d22-34) } \\
\hline Final body weight (g) & $2173.7^{\mathrm{c}} \pm 112.2$ & $1493.6^{\mathrm{b}} \pm 89.3$ & $1062.5^{\mathrm{a}} \pm 64.8$ & $2319.9^{\mathrm{d}} \pm 114.4$ & $2121.8^{\mathrm{c}} \pm 121.6$ & 69.568 & $<0.001$ \\
\hline Dry matter intake $(\mathrm{g} / \mathrm{d})$ & $145.0^{c} \pm 8.0$ & $124.8^{\mathrm{b}} \pm 11.1$ & $96.0^{\mathrm{a}} \pm 4.5$ & $138.0^{c} \pm 9.9$ & $144.4^{\mathrm{c}} \pm 9.0$ & 2.928 & $<0.001$ \\
\hline Feed conversion ratio (g/g) & $1.44^{\mathrm{b}} \pm 0.07$ & $1.88^{\mathrm{c}} \pm 0.21$ & $2.05^{\mathrm{c}} \pm 0.18$ & $1.29^{\mathrm{a}} \pm 0.07$ & $1.48^{\mathrm{b}} \pm 0.04$ & 0.045 & $<0.001$ \\
\hline Protein conversion ratio (g/g) & $0.32^{\mathrm{ab}} \pm 0.02$ & $0.42^{\mathrm{c}} \pm 0.05$ & $0.43^{c} \pm 0.04$ & $0.29^{\mathrm{a}} \pm 0.02$ & $0.32^{\mathrm{b}} \pm 0.01$ & 0.009 & $<0.001$ \\
\hline \multicolumn{8}{|l|}{ Whole trial (d1-34) } \\
\hline Final body weight (g) & $2173.7^{\mathrm{c}} \pm 112.2$ & $1493.6^{\mathrm{b}} \pm 89.3$ & $1062.5^{\mathrm{a}} \pm 64.8$ & $2319.9^{\mathrm{d}} \pm 114.4$ & $2121.8^{\mathrm{c}} \pm 121.6$ & 69.568 & $<0.001$ \\
\hline Average daily gain (g/d) & $64.54^{\mathrm{c}} \pm 3.40$ & $43.86^{\mathrm{b}} \pm 2.71$ & $30.71^{\mathrm{a}} \pm 1.96$ & $68.85^{\mathrm{d}} \pm 3.47$ & $62.75^{c} \pm 3.68$ & 2.108 & $<0.001$ \\
\hline Dry matter intake (g/d) & $87.27^{\mathrm{c}} \pm 4.72$ & $75.37^{\mathrm{b}} \pm 6.17$ & $57.84^{\mathrm{a}} \pm 1.87$ & $87.09^{c} \pm 5.55$ & $86.01^{c} \pm 5.83$ & 1.750 & $<0.001$ \\
\hline Feed conversion ratio $(\mathrm{g} / \mathrm{g})$ & $1.35^{\mathrm{b}} \pm 0.04$ & $1.72^{\mathrm{c}} \pm 0.17$ & $1.89^{c} \pm 0.11$ & $1.26^{\mathrm{a}} \pm 0.04$ & $1.37^{\mathrm{b}} \pm 0.03$ & 0.037 & $<0.001$ \\
\hline Protein conversion ratio $(\mathrm{g} / \mathrm{g})$ & $0.30^{\mathrm{a}} \pm 0.01$ & $0.41^{\mathrm{b}} \pm 0.04$ & $0.42^{\mathrm{b}} \pm 0.02$ & $0.30^{\mathrm{a}} \pm 0.01$ & $0.31^{\mathrm{a}} \pm 0.01$ & 0.008 & $<0.001$ \\
\hline
\end{tabular}

$\mathrm{HM}=$ Hermetia meal diet with basic AA supply; SM = Spirulina meal diet with basic AA supply; HM+ = Hermetia meal diet with extended AA supply; SM+ $=$ Spirulina meal diet with extended AA supply. ${ }^{*}$ Mean \pm standard derivation. ${ }^{*}$ one box excluded, outlier in feed conversion ratio, detected with SPSS boxplot-test $(\mathrm{p} \leq 0.05) .{ }^{\text {abcd }}$ Mean values with different superscript letters within lines are significantly different $(\mathrm{p} \leq 0.05)$. 
the starter period, further AA fortification significantly improved all parameters also in the grower period. $\mathrm{HM}+$ and $\mathrm{SM}+$ results remained predominantly comparable to the control. Furthermore, $\mathrm{HM}+$ yielded a significantly higher $\mathrm{BW}$ and a significantly improved FCR than the control group.

Considering the growth trial as a whole, the same tendencies as in the grower period are visible. SM and HM diets produce the significantly lowest BW and FI and correspondingly impaired feed-and protein conversion ratios as compared to the remaining diets. In addition, the same trend was observed for average daily gain (ADG). Here, HM+ surpassed the growth data and the ADG of the control diet and once again obtained a superior FCR. In all other parameters, $\mathrm{HM}+$ and $\mathrm{SM}+$ demonstrated similar results to the control diet. No significant diet effect was observed on mortality $(2 \%-4 \%)$ throughout the entire five-week trial.

\subsection{Verification of the Health Status}

Histological evaluation of all representative organ tissue specimens generally revealed none to mild unspecific findings which were similarly distributed over all dietary treatments involved. Those findings comprised predominantly scarce to mild multifocal lymphohistiocytic cell foci (see Table 5), mild fibrosis of the lamina propria (gizzard), and mild hyperemia in hepatic, pulmonary or colonic tissues. However, chickens fed with diet SM revealed a slightly pronounced proliferation of the bronchus-associated lymphoid tissue (BALT) within the lung, as compared to control diet and diet HM, respectively. On the other hand, scarce inflammatory cell infiltrates were only present in the pancreas of control animals.

Table 5. Average scores of inflammatory cell infiltrates within various meat type chicken organs after feeding of different protein diets.

\begin{tabular}{cccc}
\hline Organ & $\begin{array}{c}\text { Control } \\
(\mathbf{n}=8)\end{array}$ & $\begin{array}{c}\text { HM } \\
(\mathbf{n}=8)\end{array}$ & $\begin{array}{c}\text { SM } \\
(\mathbf{n}=8)\end{array}$ \\
\hline Liver & $(+)$ & $(+)$ & $(+)$ \\
Spleen & 0 & 0 & 0 \\
Kidney & 0 & 0 & 0 \\
Pancreas & $(+)$ & 0 & 0 \\
Heart & 0 & 0 & 0 \\
Lung (BALT) & 0 & 0 & $(+)$ \\
Bursa of Fabricius & 0 & 0 & 0 \\
Proventriculus & + & + & $(+)$ \\
Ventriculus (gizzard) & 0 & 0 & 0 \\
Caeca & $(+)$ & $(+)$ & $(+)$ \\
Colon & ++ & + & + \\
\hline
\end{tabular}

Semiquantitative score (according to Gibson-Corley et al., 2013): 0 none, (+) scarce, + mild, ++ moderate, +++ marked; $\mathrm{HM}=$ Hermetia meal diet with basic AA supply, $\mathrm{SM}=$ Spirulina meal diet with basic AA supply; BALT $=$ bronchial associated lymphoid tissue. 


\subsection{Gut Morphometric Analysis}

The tissue samples of duodenum, jejunum and caecum of all treatments under study of morphometric analysis exhibited a classical histological construction respective to the associated intestinal section. The general microscopic structure was typical for each section analyzed. A specific feature of the duodenum was the presence of leaf shaped villi and straight longitudinal in shape crypts. In the jejunum finger, shaped villi and predominantly lengthwise crypts were observed. The villi of the caecum were short and conical shaped, whereas the crypts became branched and more shallow compared to other fragments. The interior of the villi and spaces between crypts were filled with loose connective tissue containing numerous blood vessels and cells associated with the immune system lymphocytes and plasma cells. There were no differences between the examined different sections of the same part of intestine across the entire analyzed treatments. The tunica submucosa and the tunica muscularis had a typical structure.

The summarized results of the gut morphometric analysis are shown in Table 6. The morphometric parameters characterizing the architecture of the mucosa varied slightly between the control diet and diets HM and SM. No significant differences were found in the length of the villi and the depth of the crypts in the duodenum and the caecum, whereas the differences were statistically significant between the experimental diets and control group in the jejunum. Figure 1

Table 6. Average morphometric parameters ${ }^{*}$ of the intestinal sections of broiler chickens dependent on the diet under study.

\begin{tabular}{|c|c|c|c|c|c|}
\hline Diets & $\begin{array}{l}\text { Control } \\
(\mathrm{n}=12)\end{array}$ & $\begin{array}{c}\text { HM } \\
(\mathrm{n}=12)\end{array}$ & $\begin{array}{c}\text { SM } \\
(\mathrm{n}=12)\end{array}$ & SEM & $p$ \\
\hline \multicolumn{6}{|l|}{ Duodenum } \\
\hline Villus length $(\mu \mathrm{m})$ & $1570.6 \pm 407.8$ & $1684.0 \pm 287.4$ & $1419.6 \pm 308.4$ & 57.782 & 0.175 \\
\hline Crypt depth $(\mu \mathrm{m})$ & $208.8 \pm 74.7$ & $189.6 \pm 54.4$ & $161.1 \pm 25.7$ & 9.557 & 0.122 \\
\hline Villi:crypt ratio & $8.24 \pm 2.99$ & $9.48 \pm 2.68$ & $9.03 \pm 2.32$ & 0.445 & 0.520 \\
\hline T. muscularis thickness $(\mu \mathrm{m})$ & $357.4^{\mathrm{b}} \pm 119.4$ & $214.0^{\mathrm{a}} \pm 46.6$ & $205.3^{\mathrm{a}} \pm 83.7$ & 18.535 & 0.001 \\
\hline \multicolumn{6}{|l|}{ Jejunum } \\
\hline Villus length $(\mu \mathrm{m})$ & $1234.8^{\mathrm{b}} \pm 185.6$ & $1022.6^{\mathrm{a}} \pm 148.5$ & $915.0^{\mathrm{a}} \pm 357.0$ & 45.936 & 0.011 \\
\hline Crypt depth $(\mu \mathrm{m})$ & $180.1^{\mathrm{b}} \pm 60.5$ & $153.2^{\mathrm{ab}} \pm 35.0$ & $136.2^{\mathrm{a}} \pm 32.6$ & 7.828 & 0.065 (tendency) \\
\hline Villi:crypt ratio & $7.49 \pm 2.44$ & $6.90 \pm 1.31$ & $6.84 \pm 2.37$ & 0.345 & 0.706 \\
\hline T. muscularis thickness $(\mu \mathrm{m})$ & $273.0 \pm 114.7$ & $255.5 \pm 97.6$ & $224.0 \pm 59.0$ & 15.499 & 0.438 \\
\hline \multicolumn{6}{|l|}{ Caecum } \\
\hline Villus length $(\mu \mathrm{m})$ & $184.8 \pm 29.2$ & $182.3 \pm 40.3$ & $167.6 \pm 18.2$ & 5.115 & 0.341 \\
\hline Crypt depth $(\mu \mathrm{m})$ & $157.7 \pm 21.8$ & $157.1 \pm 35.1$ & $170.7 \pm 63.9$ & 7.188 & 0.693 \\
\hline Villi:crypt ratio & $1.17 \pm 0.14$ & $1.20 \pm 0.29$ & $1.08 \pm 0.33$ & 0.044 & 0.536 \\
\hline T. muscularis thickness $(\mu \mathrm{m})$ & $518.7^{\mathrm{b}} \pm 163.8$ & $360.1^{\mathrm{a}} \pm 137.8$ & $336.5^{\mathrm{a}} \pm 95.7$ & 25.830 & 0.004 \\
\hline
\end{tabular}

$\mathrm{HM}=$ Hermetia meal diet with basic AA supply; $\mathrm{SM}=$ Spirulina meal diet with basic AA supply. ${ }^{\star}$ Mean \pm standard derivation. ${ }^{\text {ab }}$ Mean values with different superscript letters within lines are significantly different $(\mathrm{p} \leq 0.05)$. 


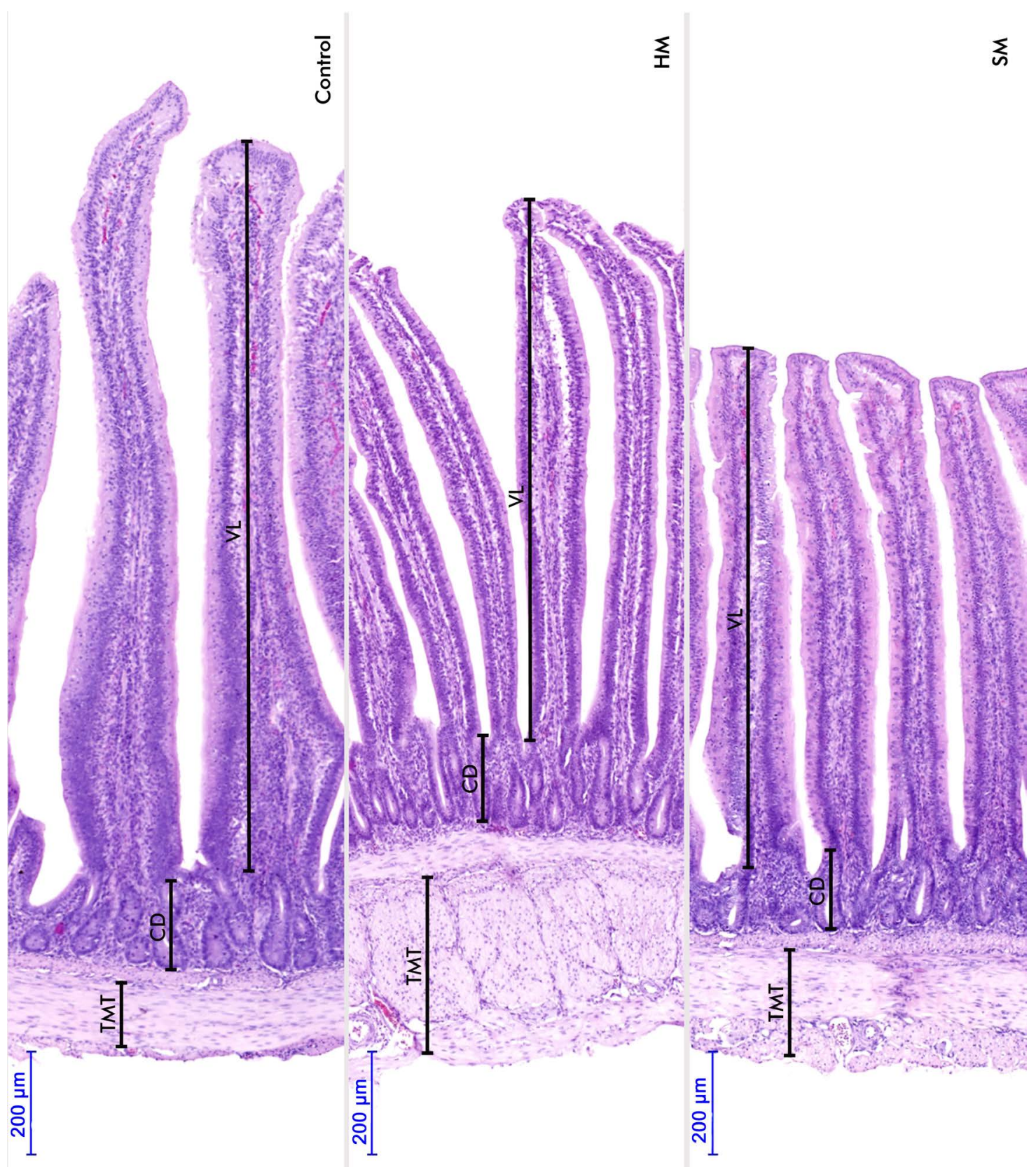

Figure 1. Histological section of the wall of jejunum and microstructure measures as applied. HE staining. Control = Control diet; $\mathrm{HM}=$ Diet with Hermetia meal at basic AA supply; SM = Diet with Spirulina meal at basic AA supply; VL = Villus length; CD = Crypt depth; TMT $=$ Tunica muscularis thickness

shows the procedure of measuring microstructure parameters of the intestinal wall.

Dietary inclusion of Hermetia illucens and Spirulina platensis meals decreased the average length of villi $(\mathrm{p}=0.011)$ in the jejunum. The HM and SM diets tended to reduce the depth of the crypts in the jejunum $(p=0.065)$. The ratio of the villus length to the depth of the crypt, referred to the intestinal integrity factor did not demonstrate any significant differences. Thickness of the tunica muscularis both of samples of the duodenum and of the caecum was significant- 
ly higher in the control group as compared to diets HM and SM ( $\mathrm{p}=0.001$ resp. $p=0.004)$. Few of enterocytes with symptoms of elevated apoptosis were observed in all dietary treatments under study.

\section{Discussion}

As demonstrated by parameters of growth response and feed efficiency, both partly defatted larvae meal from Hermetia illucens and meal of the microalgae Spirulina platensis are suitable alternative protein sources in diets for growing chickens at 50\% substitution level of SBM. However, the basic level of AA supplementation as applied in the control diet was not sufficient both in diets HM and SM to create zoo-technical responses as comparable to the control diet. This observation indicated that an extended level of AA supplementation was required for an enhanced growth response when diets with 50\% substitution of SBM are fed. Accordingly, a significant improvement of zoo-technical data was observed when AA supplementation was extended (diets $\mathrm{HM}+, \mathrm{SM}+$ ) and according to the currently assumed IAAR [22].

These observations for zoo-technical response were in general agreement with conclusions from actual $\mathrm{N}$ balance studies making use of diets with $100 \%$ substitution of SBM by Hermetia meal or Spirulina meal [26]. In consequence, diets with extended AA supplementation yielded final BW similar (diet $\mathrm{SM}+$ ) or superior ( $\mathrm{p}<0.001)$ to the control diet (diet HM+). Accordingly, [11] examined Hermetia illucens larvae as replacement for a full-fat SBM and yielded similar effects on growth response. In addition, [27] utilized 4.7\% Hermetia meal in broiler diets with an additional supplementation of Lys and Met supplementation, but observed similar BW data during starter period as in the control. These results are quite similar to the observations in the present study, but extended AA supplementation (diet $\mathrm{HM}+$ ) yielded even superior final BW as compared to the control. In case of Spirulina platensis as alternative protein source, [28] found no significant effect on BW when 14\% and 17\% Spirulina platensis were included in broiler feed. Accordingly, no significant effect on feed intake and BW was observed by [18], when $6 \%$ to $16 \%$ of Spirulina meal was included in chicken starter diets $(1-21 \mathrm{~d})$. As related to the current study, these observations are equivocal when considering the dry matter intake between control, $\mathrm{SM}+$ and HM+ diet. [29] came to similar conclusions for the grower period (21 $37 \mathrm{~d}$ ) with $8 \%$ Spirulina meal in grower diets, but the tendency was obvious that BW decreased when the Spirulina platensis inclusion rate increased. A clear growth depression was observed with diet SM on a basic level of AA supplementation. [30] came to very similar conclusions making use of the microalgae Staurosira sp. from Lower growth rate ( 0 - 3 weeks of age) and impaired feed efficiency (0 - 6 weeks of age) were observed when SBM was partly (7.5\%) substituted by the algae meal on a basic level of AA supplementation. However, if the same diets are supplemented with an extended level of indispensable AAs (Met, Lys, Arg, Ile, Thr, Trp, Val) as demonstrated in the current study, growing 
chickens yielded zoo-technical parameters as the control diet or superior results with Hermetia meal. This observation is also supported by [11]. Additionally, FCR data over the whole period responded accordingly to the BW development in the present study. [28] found no effect on FCR when 14\% and 17\% Spirulina platensis were applied. In addition, the protein conversion ratio in the current study was very similar between control and diets with extended AA supplementation, but comparable results dealing with protein efficiency of chicken diets based on alternative proteins under study are scarce in the literature.

It is well-known that the diet might influence intestinal architecture [31] [32] [33]. Although feed proteins as provided from insects and algae are believed to be a good protein source and potential ingredient in poultry diets [9] [34] [35], there is a lack of knowledge corresponding to possible effects on gut health and intestinal morphology, respectively. However, information about this "black box" could be helpful to support current processes of authorization as feed for food producing animals. Morphometric measurements of villi length and the crypts depth of the intestine are widely used as one of the factors contributing to the maintenance of intestinal homeostasis [36]. The length of villi is an important factor which determines the surface area of an intestine and in consequence the efficiency of nutrient absorption [37]. In addition, the villi-crypt ratio corresponds to the exfoliation and regeneration cycle of the intestinal epithelium.

So far, the effect of micro algae on intestinal morphology has not been studied in poultry, but in pigs. However, experiments dealing with the influence of algae on the intestinal morphology did not yield equivocal results. [38] supplemented piglets' diet with Laminaria digitata and Laminaria hyperborea extract. The most favourable morphometrical results were observed in piglets fed with a mix of brown algae Laminaria digitata and Laminaria hyperborean. The piglets with Laminaria digitata in the diet created significantly shorter villi in the duodenum and jejunum as compared to the control treatment. This result is not in agreement with observations of [39], who found an increase of villi length and the decrease of crypts depth in jejunal and ileal tissues when Spirulina platensis and Chlorella vulgaris were applied in piglet diets.

In poultry, different effects on intestinal morphology have been obtained in studies with insect meals. In free-range growing chickens, graded portions of yellow mealworm larvae (Tenebrio molitor) did not influence the morphology of bird 's intestine [40]. However, [41] have demonstrated that a Hermetia illucens added diet caused a significant increase of villi length in the duodenum of laying hens.

In the present study, a substitution of 50\% of SBM larvae meal of Hermietia illucens or microalgae Spirulina platensis did not yield a significant effect on villi length and crypts depth in the section of duodenum. However, in the section of jejunum both of the parameters declined significantly. It should be taken into account that digestion occurs in birds in the upper part of the small intestine including duodenum and the released nutrients are absorbed mainly in the lower 
part of small intestine. In consequence, the majority of nutrient absorption occurs in the jejunum and the ileum [42] which could be impaired when both villi length and crypt depth are reduced. In addition, lower depth of the crypts is an indicator for the renewal rate of epithelial tissue. Both of these aspects give support for the assumption that an adverse effect on intestinal homeostasis could be created. However, this conclusion is hypothetical and cannot be supported by the observed growth response with diets HM and SM, which was much more related to the AA deficiency as created by the basic level of AA supplementation.

Moreover, a relationship between the type of diet and the thickness of intestinal tunica muscularis of the birds was observed. The basic level of AA supplementation in diets with Hermetia illucens and Spirulina platensis resulted in a significant decrease in thickness of the tunica muscularis in duodenum and jejunum. An atrophy of the small intestinal tunica muscularis layer may indicate a lower intestinal motility [43]. This observation was surprising, but needs further attention and validation in nutritional studies before such an effect of the protein source in chicken diets can be stated. Lower gut motility could also be discussed as a factor providing more time for processes of digestion and absorption. Results of birds with extended AA supplementation support the conclusion, that an alternative protein related adverse effect on digestive and absorptive potential of the small intestine in growing chicken is improbable.

Finally, the histological evaluation of all representative organ tissue specimens provided none or only scarce to mild unspecific changes. Therefore, it is important to point out that, notable differences in the general health status were not observed between the control and experimental groups. In consequence, alternative protein meals from Hermetia illucens and Spirulina platensis inclusion rate under study did not impair the healthiness of growing chickens.

\section{Conclusions}

$50 \%$ replacement of SBM by partly defatted Hermetia or Spirulina meal in chicken diets depressed growth if AA were only supplemented at a basic level. However, with an extended level of AA supplementation growth parameters for both experimental diets were significantly improved. The morphological study of the intestinal wall yielded evidence for some detrimental effects on structure of mucosa and tunica muscularis in 50\% SMB substituted diets at basic level of AA supplementation. A specific effect of the protein source could not be concluded because lower AA balance in the diets was an overlapping factor. In addition, no histological health implications could be found when including partly defatted Hermetia illucens or algae meal of Spirulina platensis in meat type chicken diets at 50\% substitution of SBM. Comparing the two alternative protein sources under study it can be summarized, that diets with Hermetia meal achieved superior growth response and feed efficiency at both levels of AA supplementation. Nonetheless, both partly defatted Hermetia illucens and algae meal of Spirulina platensis are promising alternative protein sources in chicken 
diets when the dietary AA balance is well adapted to the IAAR through an enlarged range of supplemented feed AAs.

However, further research in gut morphometric analysis is needed in order to verify the observed effects under conditions of an extended level of AA supplementation.

\section{Acknowledgements}

This study was supported by the Lower Saxony Ministry of Science and Culture (ZN 3041).

\section{References}

[1] Alexandratos, N. and Bruinsma, J. (2012) World Agriculture towards 2030/2050: The 2012 Revision. ESA Working Paper No. 12-03, Agricultural Development Economics Division (ESA), Food and Agriculture Organization of the United Nations (FAO), Rome.

[2] FAO (2013) Edible Insects-Future Prospects for Food and Feed Security. FAO Forestry Paper No. 171, FAO, Rome, Italy.

[3] Radermacher, F.J. (2014) Die Ernährungssituation der Menschheit-Überlegungen zu einem brisanten Thema. In: VDLUFA Schriftenreihe 69. Kongressband 2013, 18-27, Berlin.

[4] Shockley, M. and Dossey, A.T. (2014) Insects for Human Consumption. In: Morales-Ramos, J.A., Guadalupe Rojas, M. and Shapiro-Ilan, D.I., Eds., Mass Production of Beneficial Organisms. Invertebrates and Entomopathogens, Academic Press, 617-652. https://doi.org/10.1016/B978-0-12-391453-8.00018-2

[5] Finke, M.D. (2002) Complete Nutrient Composition of Commercially Raised Invertebrates Used as Food for Insectivores. Zoo Biology, 21, 269-285. https://doi.org/10.1002/zoo.10031

[6] Finke, M.D. (2004) Nutrient Content of Insects-Organic Value Recovery Solution Studies. In: Encyclopedia of Entomology, Springer, Dordrecht. https://doi.org/10.1007/0-306-48380-7_2920

[7] Finke, M.D. (2013) Complete Nutrient Content of Four Species of Feeder Insects. Zoo Biology, 32, 27-36. https://doi.org/10.1002/zoo.21012

[8] Van Huis, A., Dicke, M. and van Loon, J.J.A. (2015) Insects to Feed the World. Journal of Insects as Food and Feed, 1, 3-5. https://doi.org/10.3920/JIFF2015.x002

[9] Makkar, H.P.S., Tran, G., Heuzé, V. and Ankers, P. (2014) State-of-the-Art on Use of Insects as Animal Feed. Animal Feed Science and Technology, 197, 1-33. https://doi.org/10.1016/j.anifeedsci.2014.07.008

[10] De Marco, M., Sartínez, S., Hernandez, F., Madrid, J., Gai, F., Rotolo, L., Belforti, M., Bergero, D., Katz, H., Dabbou, S., Kovitvadhi, A., Zoccarato, I., Gasco, L. and Schiavone, A. (2015) Nutritional Value of Two Insect Larvae Meals (Tenebrio molitor and Hermetia illucens) for Broiler Chickens: Apparent Nutrient Digestibility, Apparent Ileal Amino Acid Digestibility and Apparent Metabolizable Energy. Animal Feed Science and Technology, 209, 211-218. https://doi.org/10.1016/j.anifeedsci.2015.08.006

[11] Oluokun, J.A. (2000) Upgrading the Nutritive Value of Full-Fat Soybeans Meal for Broiler Production with either Fishmeal or Black Soldier Fly Larvae Meal (Hermetia Illucens). Nigerian Journal of Animal Science, 3. 
[12] Schiavone, A., De Marco, M., Rotolo, L., Belforti, M., Martinez Mirò, S., Madrid Sanchez, J., Hernandez Ruiperez, F., Bianchi, C., Sterpone, L., Malfatto, V., Katz, H., Zoccarato, I., Gai, F. and Gasco, L. (2014) Nutrient Digestibility of Hermetia illucens and Tenebrio molitor Meal in Broiler Chickens. Proceedings 1 st International Conference Insects to Feed the World, Wageningen, 14-17 May 2014, 73.

[13] Vantomme, P. (2015) Way Forward to Bring Insects in the Human Food Chain. Journal of Insects as Food and Feed, 1, 121-129. https://doi.org/10.3920/JIFF2014.0014

[14] Commission Regulation (EU) 2017/893 (2017) Official Journal of the European Union of 24 May 2017 Amending Annex I and IV to Regulation (EC) No 999/2001 of the European Parliament and of the Council and Annexes X, XIV and XV to Commission Regulation (EU) No 142/2011 as Regards the Provisions on Processed Animal Protein. L 138/92-L138/116.

[15] Ross, E. and Dominy, W. (1990) The Nutritional Value of Dehydrated, Blue-Green Algae (Spirulina platensis) for Poultry. Poultry Science, 69, 794-800. https://doi.org/10.3382/ps.0690794

[16] Bellof, G. and Carrasco Alarcon, L.S. (2013) Effect of Spirulina platensis in Organic Broiler Production. Einsatz der Mikroalge Spirulina platensis in der ökologischen Broilermast. Archiv für Geflügelkunde, 77, 73-80.

[17] Gongnet, G.P., Niess, E., Rodehutscord, M. and Pfeffer, E. (2001) Algae-Meal (Spirulina platensis) from Lake Chad Replacing Soybean-Meal in Broiler Diets. Archiv für Geflügelkunde, 65, 265-268.

[18] Evans, A.M., Smith, D.L. and Moritz, J.S. (2015) Effects of Algae Incorporation into Broiler Starter Diet Formulations on Nutrient Digestibility and 3 to $21 \mathrm{~d}$ Bird Performance. Journal of Applied Poultry Research, 24, 206-214. https://doi.org/10.3382/japr/pfv027

[19] Pan, D. and Yu, Z. (2013) Intestinal Microbiome of Poultry and Its Interaction with Host and Diet. Gut Microbes, 5, 108-119. https://doi.org/10.4161/gmic.26945

[20] Amerah, A.M. and Ravindran, V. (2008) Influence of Method of Whole-Wheat Feeding on the Performance, Digestive Tract Development and Carcass Traits of Broiler Chickens. Animal Feed Science and Technology, 147, 326-339. https://doi.org/10.1016/j.anifeedsci.2008.01.014

[21] Aviagen (2014) Ross Broiler Management Handbook. http://en.aviagen.com/assets/Tech_Center/Ross_Broiler/Ross-Broiler-Handbook-20 14i-EN.pdf

[22] Wecke, C. and Liebert, F. (2013) Improving the Reliability of Optimal In-Feed Amino Acid Ratios Based on Individual Amino Acid Efficiency Data from N Balance Studies in Growing Chicken. Animals, 3, 558-573. https://doi.org/10.3390/ani3030558

[23] WPSA (1984) The Prediction of Apparent Metabolizable Energy Values for Poultry in Compound Feeds. World s Poultry Science Journal, 40, 181-182.

[24] Naumann, C. and Bassler, R. (1976-2004) Die chemische Untersuchung von Futtermitteln. Methodenbuch, Volume III, VDLUFA-Verlag, Darmstadt.

[25] Gibson-Corley, K.N., Oliver, A.K. and Meyerholz, D.K. (2013) Principles for Valid Histopathologic Scoring in Research. Veterinary Pathology, 50, 1007-1015. https://doi.org/10.1177/0300985813485099

[26] Neumann, C., Velten, S. and Liebert, F. (2018) Improving the Dietary Protein Quality by Amino Acid Fortification with a High Inclusion Level of Micro Algae (Spiru- 
lina platensis) or Insect Meal (Hermetia illucens) in Meat Type Chicken Diets. Open Journal of Animal Sciences, 8, 12-26. https://doi.org/10.4236/ojas.2018.81002

[27] Elwert, C., Knips, I. and Katz, H. (2010) A Novel Protein Source: Maggot Meal of the Black Soldier Fly (Hermetia illucens) in Broiler Feed. In: Gierus, M., Kluth, H., Bulang, M. and Kluge, H., Eds., Tagung Schweine und Geflügelernährung, Institut für Agrar-und Ernährungswissenschaften, Universität Halle Wittenberg, 140-142.

[28] Venkataraman, L.V., Somasekaran, T. and Becker, E.W. (1994) Replacement Value of Blue-Green Alga (Spirulina platensis) for Fishmeal and a Vitamin-Mineral Premix for Broiler Chicks. British Poultry Science, 35, 373-381. https://doi.org/10.1080/00071669408417702

[29] Toyomizu, M., Sato, K., Taroda, H., Kato, T. and Akiba, Y. (2001) Effects of Dietary Spirulina on Meat Colour in Muscle of Broiler Chickens. British Poultry Science, 42, 197-202. https://doi.org/10.1080/00071660120048447

[30] Austic, R.E., Mustafa, A., Jung, B., Gatrell, S. and Lei, X.G. (2013) Potential and Limitation of a New Defatted Diatom Microalgal Biomass in Replacing Soybean Meal and Corn in Diets for Broiler Chickens. Journal of Agricultural Food Chemistry, 61, 7341-7348. https://doi.org/10.1021/jf401957z

[31] Laudadio, V., Passantino, L., Perillo, A., Lopresti, G., Passantino, A., Khan, R.U. and Tufarelli, V. (2012) Productive Performance and Histological Features of Intestinal Mucosa of Broiler Chickens Fed Different Dietary Protein Levels. Poultry Science, 91, 265-270. https://doi.org/10.3382/ps.2011-01675

[32] Gopinger, E., Xavier, E.G., Elias, M.C., Catalan, A.A., Castro, M.L., Nunes, A.P. and Roll, V.F. (2014) The Effect of Different Dietary Levels of Canola Meal on Growth Performance, Nutrient Digestibility, and Gut Morphology of Broiler Chickens. Poultry Science, 93, 1130-1136. https://doi.org/10.3382/ps.2013-03426

[33] Qaisrani, S.N., Moquet, P.C., van Krimpen, M.M., Kwakkel, R.P., Verstegen, M.W. and Hendriks, W.H. (2014) Protein Source and Dietary Structure Influence Growth Performance, Gut Morphology, and Hindgut Fermentation Characteristics in Broilers. Poultry Science, 93, 3053-3064. https://doi.org/10.3382/ps.2014-04091

[34] Veldkamp, T., van Duinkerken, G., van Huis, A., Iakemond, C.M.M., Ottevanger, E., Bosch, G. and Van Boekel, M.A.J.S. (2012) Insects as a Sustainable Feed Ingredient in Pig and Poultry Diets-A Feasibility Study. Wageningen UR Livestock Research, Report 638.

[35] Van Huis, A. (2013) Potential of Insects as Food and Feed in Assuring Food Security. Annual Review of Entomology, 58, 563-583. https://doi.org/10.1146/annurev-ento-120811-153704

[36] Franco, J.R.G., Murakami, A.E., Natali, M.R.M., Garcia, E.R.M. and Furlan, A.C. (2006) Influence of Delayed Placement and Dietary Lysine Levels on Small Intestine Morphometrics and Performance of Broilers. Brazilian Journal of Poultry Science, 8, 233-241. https://doi.org/10.1590/S1516-635X2006000400006

[37] Caspary, W.F. (1992) Physiology and Pathophysiology of Intestinal Absorption. The American Journal of Clinical Nutrition, 55, 299-308. https://doi.org/10.1093/ajcn/55.1.299s

[38] Reilly, P., O’Doherty, J.V., Pierce, K.M., Callan, J.J., O’Sullivan, J.T. and Sweeney, T. (2008) The Effects of Seaweed Extract Inclusion on Gut Morphology, Selected Intestinal Microbiota, Nutrient Digestibility, Volatile Fatty Acid Concentrations and the Immune Status of the Weaned Pig. Animal, 2, 1465-1473. https://doi.org/10.1017/S1751731108002711

[39] Furbeyre, H., van Milgen, J., Mener, T., Gloaguen, M. and Labussière, E. (2017) Ef- 
fects of Dietary Supplementation with Freshwater Microalgae on Growth Performance, Nutrient Digestibility and Gut Health in Weaned Piglets. Animal, 11, 183-192. https://doi.org/10.1017/S1751731116001543

[40] Biasato, I., De Marco, M., Rotolo, L., Renna, M., Dabbou, S., Capucchio, M.T, Biasibetti, E., Tarantola, M., Costa, P., Gai, F., Pozzo, L., Dezzutto, D., Bergagna, S., Gasco, L. and Schiavone, A. (2016) Effects of Dietary Tenebrio molitor Meal Inclusion in Free-Range Chickens. Journal of Animal Physiology and Animal Nutrition, 100, 1104-1112. https://doi.org/10.1111/jpn.12487

[41] Cutrignelli, M.I., Messina, M., Tulli, F., Randazzo, B., Olivotto, I., Gasco, L., Loponte, R. and Bovera, F. (2018) Evaluation of an Insect Meal of the Black Soldier Fly (Hermetia illucens) as Soybean Substitute: Intestinal Morphometry, Enzymatic and Microbial Activity in Laying Hens. Research in Veterinary Science 117, 209-215. https://doi.org/10.1016/j.rvsc.2017.12.020

[42] Tasaki, I. and Takahashi, N. (1966) Absorption of Amino Acids from the Small Intestine of the Domestic Fowl. Journal of Nutrition, 88, 359-364.

https://doi.org/10.1093/jn/88.4.359

[43] Couraud, L., Jermyn, K., Yam, P.S., Ramsey, I.K. and Philbey, A.W. (2006) Intestinal Pseudo-Obstruction, Lymphocytic Leiomyositis and Atrophy of the Muscularis Externa in a Dog. Veterinary Record, 159, 86-87.

https://doi.org/10.1136/vr.159.3.86 